\title{
PERGESERAN HALMAHERA EDDY KAITANNYA DENGAN PRODUKTIVITAS TANGKAPAN IKAN CAKALANG DI PERAIRAN SEKITARNYA
}

\author{
HALMAHERA EDDY DISPLACEMENT IN RELATION TO PRODUCTIVITY SKIPJACK \\ IN SURROUNDING WATERS
}

\author{
Gentio Harsono $^{1}$, Supartono ${ }^{1}$, D. Manurung ${ }^{2}$, Agus S. Atmadipoera ${ }^{2}$, \\ Mulyono S. Baskoro ${ }^{3}$, Fadli Syamsudin ${ }^{4}$ \\ ${ }^{1}$ Sekolah Staf Komando Angkatan Laut \\ ${ }^{2}$ Departemen Ilmu dan Teknologi Kelautan \\ Fakultas Perikanan dan Ilmu Kelautan, Institut Pertanian Bogor \\ ${ }^{3}$ Departemen Pemanfaatan Sumberdaya Perikanan \\ Fakultas Perikanan dan Ilmu Kelautan, Institut Pertanian Bogor \\ Korespondensi :
}

\begin{abstract}
The water between Mindanao and New Guinea is one of areas fisheries potential skipjack (Katsuwanus pelamis) most advanced in the western pacific. The main of fisheries industry this type of dominated by purse-seine by large size (50-100 Gross Tonnage). The role of a Halmahera Eddy is very importance in the dynamics of fisheries in the region, but there is no that explain it yet. Data series arrest skipjack catch per unit of effort (CPUE) of Western Central Pacific Fisheries Commission (WCPFC) for a decade the period July 2002-December 2012 analyzed in order to see the relationship between shifting Halmahera Eddy with the productivity skipjack in the study areas. The results show that the productivity skipjack in the study areas correlates strongly against a meridional shifting of Halmahera Eddy where CPUE showing an increase in skipjack with lag time on two months after Halmahera Eddy center shifted to the north. While to zonal shifting have a correlation in which weak.
\end{abstract}

Keywords: Catch per Unit Effort, Halmahera Eddy, skipjack, purse seine

\begin{abstract}
ABSTRAK
Perairan antara Mindanao dan Papua merupakan salah satu wilayah potensial perikanan cakalang (Katsuwanus pelamis) yang paling maju di Pasifik barat. Sebagian besar industri perikanan jenis ini didominasi oleh kapal jenis purse-seine dengan ukuran besar (50-100 GT). Peran arus pusar Halmahera menjadi penting dalam dinamika perikanan di wilayah ini, namun belum ada yang menjelaskannya. Seri data penangkapan cakalang Catch per Unit Effort (CPUE) dari Western Central Pacific Fisheries Commission (WCPFC) selama satu dekade periode Juli 2002-Desember 2012 dianalisis guna melihat hubungan antara pergeseran Halmahera Eddy dengan produktivitas ikan cakalang di wilayah studi. Hasilnya menunjukkan bahwa produktivitas ikan cakalang di wilayah studi berkorelasi kuat terhadap pergeseran meridional Halmahera Eddy di mana CPUE cakalang memperlihatkan peningkatan dengan jeda waktu 2 bulan setelah pusat Halmahera Eddy bergeser ke utara sedangkan untuk pergeseran zonalnya mempunyai korelasi yang lemah.
\end{abstract}

Kata kunci: Catch per Unit Effort, Halmahera Eddy, produktivitas cakalang, purse seine

PENDAHULUAN

Perairan antara Mindanao - Papua New Guinea (PNG) merupakan bagian dari wilayah Warm Pool (WP) yang selama ini selain dikenal dengan suhu permukaan lautnya terhangat di dunia $\left(>29^{\circ} \mathrm{C}\right)$ juga merupakan perairan yang miskin akan produktivitas primernya (oligotropik) di mana konsentrasi klrofil-a permukaan < $0.1 \mathrm{mg} / \mathrm{m}^{3}$ (Messie \&Radenac 2006). Ditambahkan oleh Sprintall and Tomczak (1992) dan Allain et al. (2007), perairan WP mempunyai ciri pada lapisan permukaannya berupa salinitas permukaan yang rendah (umumnya <33.5 PSU), akibat presipitasi lebih tinggi dibandingkan evaporasinya, adanya lapisan gendala (barrier layer) yang menghalangi massa air lapisan bawahnya melakukan intrusi ke lapisan atasnya yang berakibat kandungan unsur nitratnya rendah.

Wilayah daratan sekitar HE merupakan perairan yang masuk dalam segitiga pertumbuhan karang dunia mulai dari pantai sekitar Jayapura, perairan Raja Ampat hingga Pulau Morotai di utara Halmahera. Wilayah 
terumbu karang ini dikenal mempunyai tingkat produktivitas perairan tinggi. Hal ini dapat terlihat dengan jelas citra Sea WiFS maupun Aqua MODIS. Interaksi internal tide dengan sill di selat Halmahera serta sungaisungai besar seperti Membramo dan Matabori juga membawa sejumlah besar nutrien masuk dalam aliran arus permukaan New Guinea Coastal Current (NGCC) ini (Burns et al. 2007); Muchtar 2004). Demikian pula halnya dengan pengaruh Laut Maluku yang mempunyai intensitas up welling cukup tinggi terutama saat musim tenggara.

Eddy selama ini dikenal sebagai sumber utama variabilitas dalam proses biologi dan biogeokimia di lautan terbuka (Siegel et al. 2008). Berbagai jenis ikan pelagis di perairan seluruh dunia berkorelasi erat dengan wilayahwilayah perairan dimana eddy terbentuk ini terbentuk (Zainuddin et al. 2006). Meskipun perairannya termasuk dalam kategori oligotropik, namun kondisinya sangat kontras dengan produktivitas perikanannya (Lehodey et al. 1997; Messie \& Radenac 2006). Selain peran Eddy sendiri yang sudah dikenal dalam transportasi massa air, salinitas dan bahang di sejumlah samudera (Kurogano \& Kamachi 2003; Kashino et al. 1999).

Pemanfaatan citra klorofil permukaan untuk identifikasi suatu Eddy maupun ring telah dilakukan beberapa peneliti. Souza et al. (2002) dengan menggunakan satelit Sea WiFS, altimetri dan pengukuran hidrografi insitu berhasil mendeteksi aktivitas Eddy di selatan wilayah pertemuan Brazil-Malvinas meliputi life cycle, dimensi, suhu permukaan laut (SPL), konsentrasi klorofil-a permukaan, anomali tinggi muka laut serta pergeseran terhadap suatu Eddy. Sementara Kai \& Marsac (2010) menginvestigasi sejumlah Eddy skala menengah (meso-scale eddy) di kanal Mozambique Samudera Hindia barat dengan menggunakan citra altimetri, suhu permukaan laut dan sebaran klorofil-a sebagai kunci dalam menentukan karakteristik Eddy dan habitat perairannya. Demikian pula halnya Veldoven (2005) mengidentifikasi Eddy/ring di perairan Agulhas dengan citra altimeteri yang sebelumnya belum dipublikasikan yang kemudian menamakan Eddy/ring tersebut dengan nama dirinya. Penelitian yang paling mendekati dalam menjelaskan biologi di sekitar pusaran arus Halmahera dilakukan oleh Christian et al. (2004). Mereka melihat fenomena munculnya blooming phytoplankton yang membentuk seperti pita gelap (ribbon of dark) disepanjang sumbu ASKU ketika episode El Niño berlangsung. Sedangkan Harsono et al. (2014) berhasil mengidentifikasi Halmahera
Eddy dan pergeserannya menggunakan seri data citra klorofil-a dari data Aqua MODIS.

Kashino et al. (2013) dengan menggunakan seri data SADCP pelayaran TOCS tahun 2006 (mewakili musim barat lauttahun El Niño), TOCS 2007 (mewakili musim barat laut-tahun La Niña), TOCS 2011 (musim tenggara-tahun Normal) dan TOCS 2013 (mewakili musim barat laut-tahun Normal) menyebutkan bahwa selama tahun El Niño, $\mathrm{HE}$ bergeser ke selatan di sekitar $3^{\circ} \mathrm{N} 131{ }^{\circ} \mathrm{E}$ dan selama tahun La Niña, HE bergeser ke barat laut disekita $5{ }^{\circ} \mathrm{N} / 129{ }^{\circ} \mathrm{E}$. Sedangkan selama musim tenggara, $\mathrm{HE}$ terlihat bergeser ke utara di sekitar $5{ }^{\circ} \mathrm{N} / 129^{\circ} \mathrm{E}$ dan selama musim barat laut bergeser ke selatan di sekitar $3{ }^{\circ} \mathrm{N} / 131{ }^{\circ} \mathrm{E}$.

Pola perkembangan dan pergeseran HE diduga terkait dengan pola ruaya dan produktivitas ikan cakalang sebagai ikan permukaan yang menyukai suhu permukaan laut yang hangat. Spesies cakalang yang merupakan tuna dengan ukuran rata-rata dewasa lebih kecil dibandingkan dengan spesies tuna lainnya dan pemakan utama macrozoo plankton dan mikronekton. Spesies diet ikan cakalang ini diduga berkorelasi erat dengan dinamika oseanografi akibat pergeseran Halmahera Eddy.

\section{METODE PENELITIAN}

\section{Sumber data}

Pergeseran Halmahera Eddy. Pola pergeseran Halmahera Eddy ditentukan berdasarkan pergerakan pusat Halmahera Eddy yang diidentifikasi berdasarkan jejak klorofil-a yang terbawa pusaran arus Halmahera dan membentuk rona, dengan demikian pergeseran Halmahera Eddy dikenali melalui rona (feature) sebaran klorofil permukaan ini dari citra yang dibuat (Harsono et al. 2014).

Data sebaran konsentrasi klorofil-a permukaan yang digunakan merupakan seri data citra satelit Aqua-MODIS Level-3 komposit bulanan resolusi spasial 0.05 $\mathrm{km} \times 4 \mathrm{~km}$ ) selama rentang waktu bulan Juli 2002-Desember 2012.

Citra klorofil ini merupakan sumber utama dalam pengamatan dan pencatatan data statistik yang akan diambil untuk analisis deret waktu (time series). Proses pengolahan data klorofil-a permukaan Aqua MODIS menjadi citra dilakukan dengan bantuan perangkat lunak Arch GIS Ver. 10.1, sedangkan analisis deret waktu menggunakan perangkat lunak Matlab Ver. 7.0. 


\section{Data perikanan tangkap cakalang (Katsuwonus pelamis)}

Data perikanan tuna cakalang yang digunakan berasal dari data perikanan tangkap lainnya adalah produktivitas ikan cakalang yang diperoleh dari Western Central Pacific Fisheries Commission (WCPFC) dalam klasifikasi public domain. Data produktivitas ikan cakalangyang digunakan dalam penelitian ini berasal dari hasil tangkapan kapal purse seine dimana cakalang yang ditangkap adalah yang beruaya bebas (free schooling) dan bukan berasal dari hasil tangkapan disekitar gelondongan kayu yang mengapung atau dari penangkapan sekitar rumpon. Data penangkapan cakalang yang digunakan adalah dalam batas-batas koordinat $0^{\circ} \mathrm{N}-5^{\circ} \mathrm{N}$ dan $130^{\circ} \mathrm{E}-135^{\circ} \mathrm{E}$. Data yang ini diunduh dari website: http://www.wcpfc.int/doc.

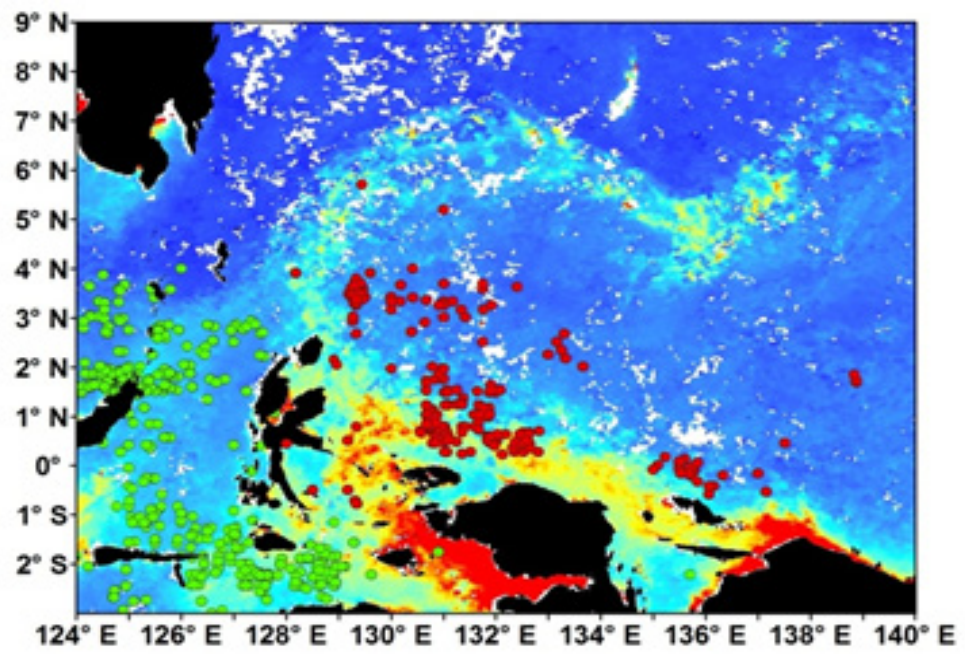

Gambar 1. Halmahera Eddy diidentifikasi berdasarkan data citra klorofil-a dari Aqua Modis. Terlihat sebaran kapal purse seine (titik warna merah dan hijau di sekitar pusaran Halmahera Eddy (Harsono et al. 2014)

\section{HASIL DAN PEMBAHASAN}

Pada Gambar 1 diperlihatkan sebaran kapal purse-seine saat melakukan operasi penangkapan di sekitar wilayah kajian. Kapal jenis purse-seine merupakan jenis kapal yang digunakan dalam menangkap cakalang di wilayah pengelolaan pasifik barat dan tengah. Berdasarkan gambar tersebut ditunjukkan bahwa lokasi-lokasi dimana kapal purse-seine melakukan penangkapan berada (terkonsentrasi) di dalam dan disekitar sabuk klorofil-a permukaan tinggi. Hal ini kemungkinan disebabkan oleh sifat biologi cakalang yang merupakan tuna permukaan yang menyukai air hangat. Pertemuan antara massa air hangat yang dibawa oleh arus Pantai Utara Papua (NGCC/NGCUC) dengan massa air yang lebih rendah suhunya dari perairan dalam sekitar Indonesia menyebabkan konsentrasi ikan cakalang cenderung di sekitar utara kepala burung Papua dan timur laut Halmahera. Namun demikian, konsentrasi kapa-kapal purse-seine yang beroperasi di wilayah ini sangat tergantung adanya rumpon (Fish Aggregation Device/FAD). Sehingga posisi purse-seine yang diplot dalam peta tersebut kemungkinan juga merupakan posisi purse-seine saat menangkap ikan di rumpon.

\section{Hubungan pergeseran Halmahera Eddy dengan produktivitas cakalang}

Pada Gambar 2, disajikan peta wilayah perairan studi yang menjadi wilayah pengambilan data perikanan cakalang (dalam tanda kotak warna merah), berada dalam area lintang $0-5^{\circ} \mathrm{N}$ dan bujur $130{ }^{\circ} \mathrm{E}-135^{\circ} \mathrm{E}$. Dalam peta tersebut juga ditumpangsusunkan (overlay) dengan sebaran titik pusat HE selama penelitian berlangsung (Juni 2002-Desember 2012).

Jumlah tangkapan per unit usaha (Catch Per Unit Effort/CPUE) dalam wilayah sampling selama penelitian berlangsung disajikan pada Gambar 3. Berdasarkan grafik pada gambar tersebut menunjukkan bahwa jumlah tangkapan mengalami peningkatan mencolok pada periode 20022003 dan jumlah tangkapan maksimum pada tahun 2009-2010 dan tahun 2012. Menurut Lehaodey et al. (2011) peningkatan jumlah tangkapan cakalang selama periode 2009-2010 disebabkan karena meningkatnya jumlah kapal purse-seine yang merupakan kapal dengan ikan target cakalang.

Pada Gambar 4 disajikan grafik variasi musiman CPUE yang diperoleh dari analisis deret waktu data tangkapan cakalang di 
wilayah sampling.

Berdasarkan Gambar 4 tersebut, dapat diketahui bahwa produktivitas cakalang umumnya tinggi saat pertengahan tahun (sekitar Mei-Juli) dan menurun saat akhir dan awal tahun. Selama tahun 2002-2008, produktivitas cakalang mengalami fase calm dimana produktivitas umumnya stagnan, namun pada 2009 sampai akhir 2012, produktivitas terlihat mengalami perubahan kenaikan yang tajam. Bila dikaitkan dengan pergeseran meridional $\mathrm{HE}$ dalam skala musiman, maka akan terlihat pola kesamaan perubahan amplitudo berupa peningkatan kisaran amplitudo selama kurun waktu 20092012. Fluktuasi CPUE terendah terjadi pada peralihan tahun 2002-2003 dan tertinggi terjadi tahun 2010. Kondisi ini kemungkinan terkait akibat pengaruh pergeseran iklim yang menyebabkan perubahan kondisi oseanografi di wilayah tersebut.

Pada Gambar 5 disajikan grafik variasi antartahunan CPUE cakalang pada wilayah sampling. Berdasarkan gambar tersebut, dapat diketahui bahwa CPUE cakalang mengalami peningkatan selama 2002, 2005, 2010 dan 2012 dan mengalami penurunan pada peralihan tahun 2003-2004, 2008 dan 2011.

Terkait dengan pergeseran $\mathrm{HE}$, guna melihat pengaruh pergeseran $\mathrm{HE}$ dengan CPUE cakalang maka dilakukan uji korelasi terhadap kedua parameter tersebut. Pada Gambar 6 (a) disajikan grafik tumpangsusun antara pergeseran meridional $\mathrm{HE}$ dengan jumlah CPUE cakalang. Hasil perhitungan uji korelasi (lag correlation) pada taraf kepercayaan 95\% diperoleh nilai koefisien korelasi r sebesar 0.72 dengan jeda waktu (time lag) selama 2 bulan (Gambar 7b). Hal ini menunjukkan bahwa pergeseran meridional Halmahera
Eddy mempunyai pengaruh kuat terhadap fluktuasi CPUE cakalang di wilayah area yang menjadi lokasi sampling. Ketika Halmahera Eddy bergeser ke utara, 2 bulan kemudian kondisi oseanografi di lingkungan area sampling meresponnya dengan meningkatnya produktivitas cakalang.

Gambar 6 (b) menyajikan grafik tumpangsusun pergeseran zonal $\mathrm{HE}$ dengan CPUE cakalang wilayah sampling. Hasil uji korelasi terhadap kedua parameter tersebut diperoleh nilai koefisien korelasi $r=-0.22$ pada taraf kepercayaan 95\%. Hal ini menunjukkan bahwa hubungan pergeseran zonal dengan CPUE cakalang di wilayah sampling mempunyai tingkat korelasi yang lemah sehingga pengaruhnya kecil (Gambar 7a).

Fenomena tersebut menunjukkan bahwa dinamika oseanografi yang terjadi akibat pergeseran meridional lebih kuat pengaruhnya terhadap CPUE cakalang di wilayah sampling dibandingkan pergeseran zonalnya. Cakalang merupakan spesies tuna permukaan yang menyukai lingkungan perairan dengan suhu permukaan laut yang hangat. Ketika WP mengalami relaksasi dengan bergeser ke Pasifik tengah, maka HE akan merespons pergerakan WP tersebut dengan bergeser ke tenggara. Selama periode tersebut cakalang akan beruaya mengikuti pergerakan WP tersebut ke arah timur yang menyebabkan jumlah CPUE di wilayah studi menurun. Sebaliknya ketika WP semakin intensif di Pasifik Barat, HE meresponsnya dengan bergeser ke barat laut dan ruaya cakalang cenderung berada di wilayah yang menjadi sampling menyebabkan CPUE cakalang di wilayah tersebut meningkat.

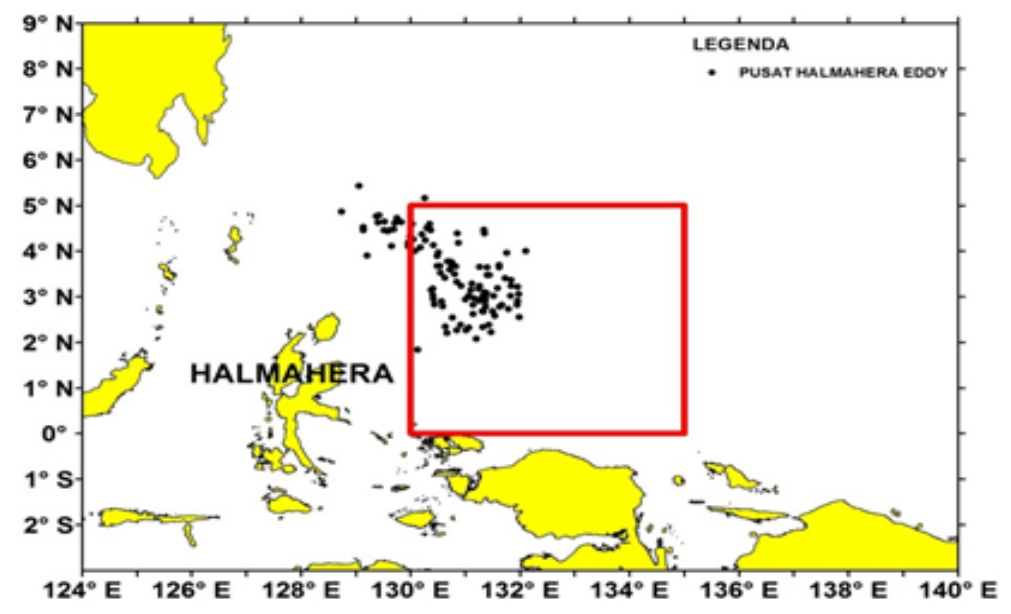

Gambar 2. Peta lokasi sampling data perikanan cakalang (kotak warna merah) dan sebaran titik pusat Halmahera Eddy (lingkaran hitam) selama periode penelitian 


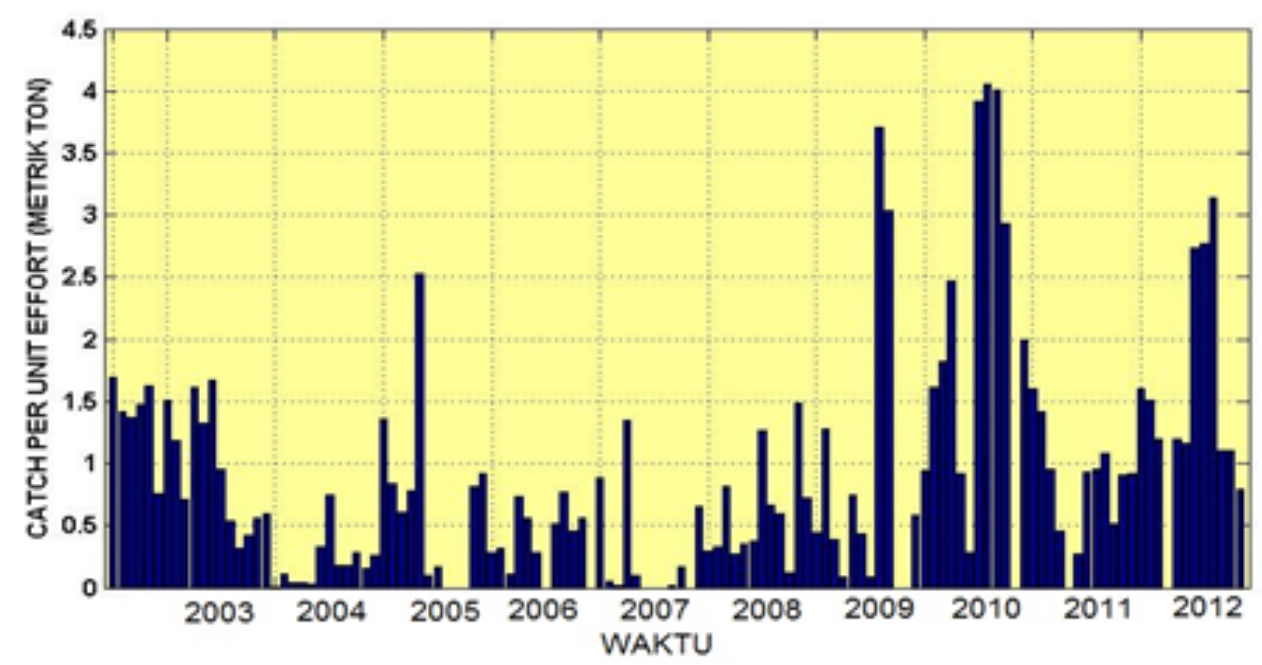

Gambar 3. Jumlah CPUE cakalang pada area perairan 0-5N / 130E-135E oleh kapal purse-seine selama periode penelitian. (Data diambil dari Public Domain Western Central Pacific Fisheries Commission (WCPFC)

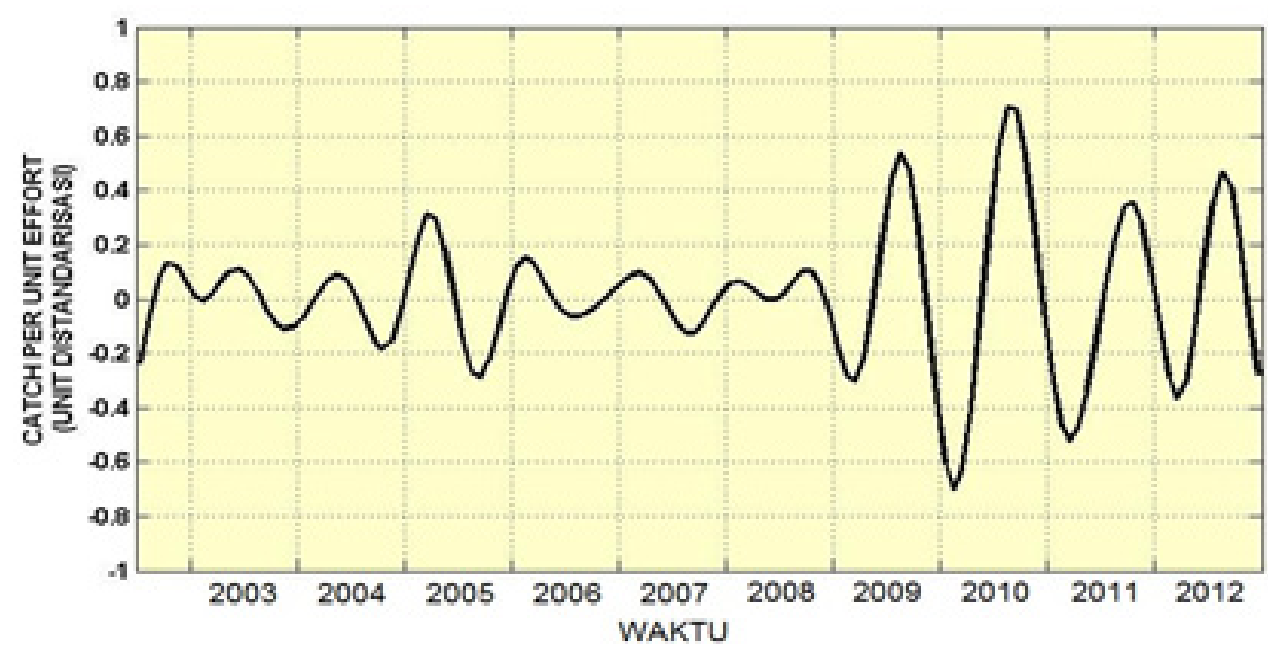

Gambar 4. Variasi musiman CPUE cakalang dalam wilayah sampling

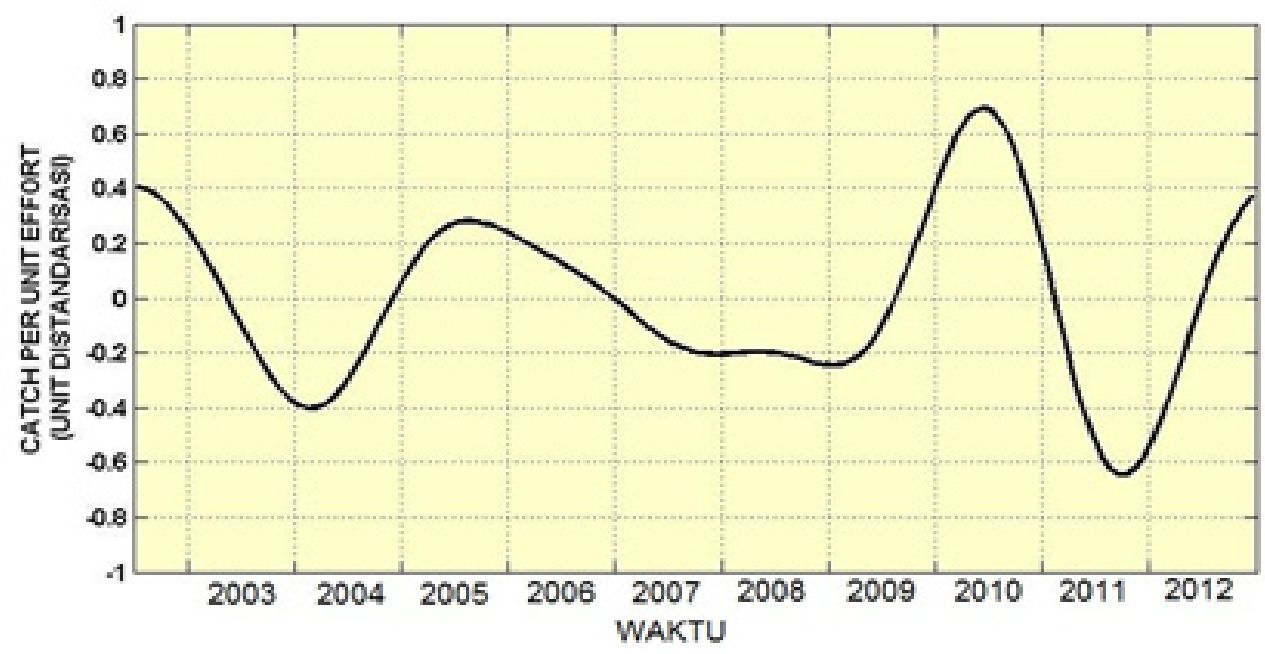

Gambar 5. Variasi antar-tahunan CPUE cakalang dalam wilayah sampling 


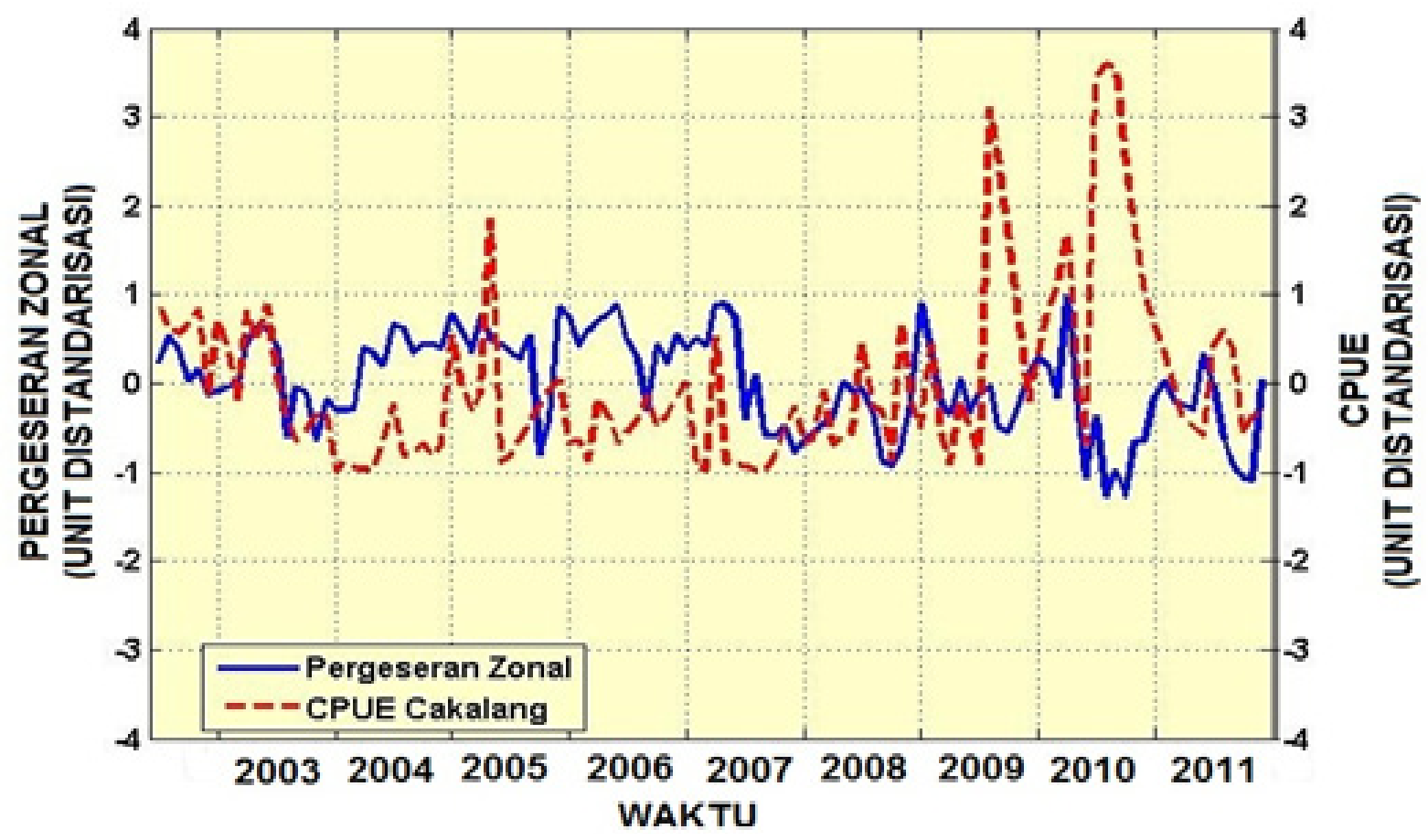

Gambar 6. Tumpangsusun jumlah tangkapan per unit usaha (CPUE) dengan pergeseran Halmahera Eddy

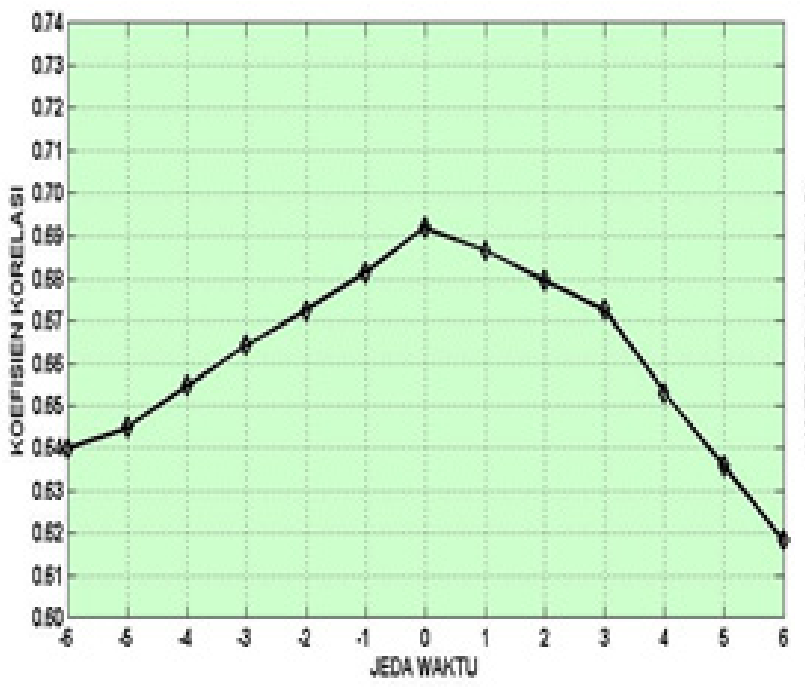

(a)

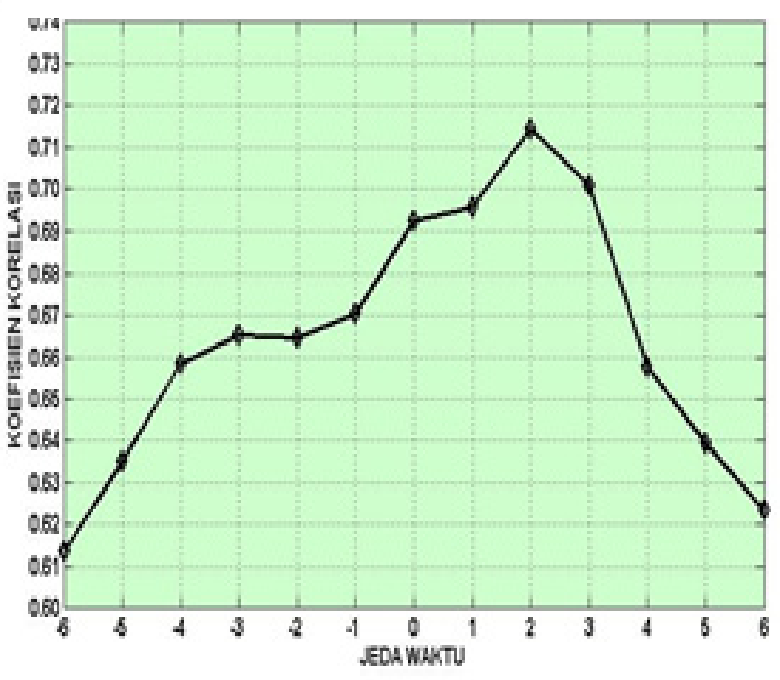

(b)

Gambar 7. Jeda Waktu (a) Zonal (b) Meridional

\section{KESIMPULAN}

Kapal-kapal purse-seine yang beroperasi di wilayah studi cenderung terkonsentrasi di wilayah bagian dalam dan tepi dari pusaran Halmahera Eddy sekitar timur laut
Halmahera dan utara kepala burung Papua. Produktivitas cakalang di wilayah studi mempunyai korelasi kuat terhadap pergeseran meridional Halmahera Eddy. CPUE cakalang memperlihatkan peningkatan dengan jeda waktu 2 bulan setelah pusat Halmahera Eddy bergeser ke utara. Pergeseran zonalnya 
mempunyai korelasi yang lemah.

\section{DAFTAR PUSTAKA}

Allain V, Nicol S, Essington T, Okey T, Olson B, Kirby D. 2007. An ecopath with ecosim model of Western and Central Pacific Ocean warmpool pelagic ecosystem. Scientific Committe Third Regular Session, Western Central Pacific Fisheries Commission, Honolulu USA.

Burns KA, Brunskill G, Brinkman D, Zagorskis. 2008. Organic carbon and nutrient fluxes to the coastal zone from the sepik river outflow. Continental Shelf Res.

Christian JR, Murtugudde R, Poy JB, McClain CR. 2004. A ribbon of dark water: phytoplankton blooms in the Meanders of Pacific North Equatorial Countercurrent. Deep Sea Research. Part II 51.

Harsono G, Atmadipoera AS, Syamsudin F, Manurung D, Baskoro MS. 2014. Halmahera Eddy features observed from multisensor satellite oceanography. As. J. of Sc. Ress. 7(4):571-580.

Harsono G, Manurung D, Atmadipoera AS, Mulyono SB, Syamsudin F, 2014. Analisis pergeseran Halmahera Eddy menggunakan data satelit multisensor dan hidrografi. Jurnal Segara Vol 10(1) hal:61-70

Harsono G. 2014. Kajian arus pusar Halmahera menggunakan data satelit multisensor dan hidrografi serta kaitannya dengan produktivitas cakalang [disertasi](tidak dipublikasikan). Bogor : Institut Pertanian Bogor

Kai ET, Marsac F. 2010. Influence of mesoscale Eddies on spatial structuring of top predators' communities in the mozambique channel. Proceeding in Ocean 86 hal:214-223.

Kashino Y, Watanabe H, Herunadi B, Aoyama M, Hartoyo D.1999. Current variability at the pacific entrance of the Indonesian throughflow. J. Geophys. Res.

Kashino Y, Atmadipoera AS, Kuroda Y, Lukijanto. 2013. Observed feature of the Halmahera and Mindanao Eddies, J. Geophys. Res.

Lehodey P, Bertignac M, Hampton J, Lewis A, Picaut J. 1997. El Nin o Southern oscillation and tuna in the Western Pacific. Nature. 389:715-718.

Lehodey P. 2001. The pelagic ecosystem of the tropical Pacific Ocean: dynamic spatial modelling and biological consequences of ENSO. Progress in Oceanography. 49:439-468

Lehodey P. 2004. A spatial ecosystem and populations dynamic model (SEAPODYM) for tuna and assosciated oceanic top-predator species: part $\mathrm{i}$ - lower and intermediate trophic components, standing committee on tuna and billfish (SCTB) 17 working paper (ECO-1), Oceanic Fisheries Programme Secretariat of The Pacific Community, Noumea:New Caledonia.

Lehodey P, Hampton J, Brill RW, Nicol S, Senina I, Sibert J. 2011. Vulnerabely of oceanic fisheries in the tropical pacific to climate change. Johnson JE and Hobdey (Eds..) Secretariat of the Pacific Community, Noumea:New Caledonia.

Messie M, Radenac MH. 2006. Seasonal variability of the surface chlorophyll in the Western tropical pacific from SeaWiFS data. Deep Sea Research. Part I 53.

Muchtar M. 2004. Indo TROPICS studies on the plume of the membramo river into the Bismarck Sea, West Papua, Indonesia. Contintental Shelf Res.

O’Reilly JE, Maritorena S, Mitchell BG, Siegel DA, Carder KL, Garver SA, Kahru M, McClain C. 1998. Ocean color algorithms for SeaWiFS. J. Geophys. Res.

Souza RB, Mata MM, Garcia CAE, Kampel M, Oliviera EN, Lorenzzetti JA. 2005. Multi-sensor satellite and in situ measurements of a warm core ocean Eddy south the Brazil-Malvinas confluence region. Remote Sensing of Environment.

Sprintall J, Tomczak M. 1992. Evidence of the barrier layer in the surface layer of the tropics. J. Geophys. Res.

Veldhoven A. 2005. Observations of evolution of agulhas rings [thesis]. Netherlands: Universiteit van Utrecht.

Zainuddin M, Kiyofuji H, Saitoh K, Saitoh S. 2006. Using multi-sensor satellite remote sensing and catch data to detect ocean hot spots for albacore (Thunnus alalunga) in the Northwestern North Pacific. Deep Sea Research. Part II 53

\section{UCAPAN TERIMA KASIH}

Terimakasih disampaikan kepada NOOA-NASA atas data chlorophyll-a dari 
data Aqua MODIS. Terimakasih juga disampaikan kepada Western-Central Pacific Fisheries Commission (WCPFC) atas data perikanan cakalang di wilayah studi. 